\title{
Recent advances in understanding Crimean-Congo
}

\section{hemorrhagic fever virus [version 1; peer review: 4 approved]}

\author{
David W. Hawman, Heinz Feldmann (D)
}

Laboratory of Virology, Division of Intramural Research, NIAID/NIH, Hamilton, Montana, 59840, USA

V1 First published: 29 Oct 2018, 7(F1000 Faculty Rev):1715

https://doi.org/10.12688/f1000research.16189.1

Latest published: 29 Oct 2018, 7(F1000 Faculty Rev):1715

https://doi.org/10.12688/f1000research.16189.1

\section{Abstract}

Crimean-Congo hemorrhagic fever virus (CCHFV) is a widely distributed hemorrhagic fever virus and the cause of hemorrhagic disease in Africa, Southern and Eastern Europe, the Middle East, India and Asia. Recent emergence of CCHFV into Spain indicates that the geographic range of this virus is expanding and the presence of its tick vector in several countries without reported disease suggest that CCHFV will continue to spread. Research into CCHFV was historically limited by a lack of suitable animal models and tools to study viral pathogenesis. However, in the past few years the toolset for studying CCHFV has expanded with small animal and non-human primate models for CCHFV being developed along with a reverse genetics system that allows for investigation of viral determinants of disease. These tools have been utilized to understand how CCHFV antagonizes host restriction factors and to develop novel vaccine candidates that may help limit the substantial morbidity and mortality in humans caused by CCHFV.

\section{Keywords}

Crimean-Congo hemorrhagic fever virus, CCHFV, CCHF disease, pathogenesis, animal models, vaccines, antivirals

\section{Open Peer Review}

Approval Status

$\begin{array}{lllll}1 & 2 & 3 & 4\end{array}$

\section{version 1}

29 Oct 2018

Faculty Reviews are review articles written by the prestigious Members of Faculty Opinions. The articles are commissioned and peer reviewed before publication to ensure that the final, published version is comprehensive and accessible. The reviewers who approved the final version are listed with their names and affiliations.

\footnotetext{
1. Anna Papa, Aristotle University of Thessaloniki, Thessaloniki, Greece

2. Dennis A Bente, University of Texas Medical Branch, Galveston, USA

\section{Ali Mirazimi, Karolinska Institute and} Karolinska Hospital University, Solna, Sweden National Veterinary Institute, Uppsala, Sweden
4. Eric Bergeron, Centers for Disease Control and Prevention, Atlanta, USA

Any comments on the article can be found at the end of the article. 
Corresponding author: David W. Hawman (david.hawman@nih.gov)

Author roles: Hawman DW: Writing - Original Draft Preparation, Writing - Review \& Editing; Feldmann H: Writing - Original Draft Preparation, Writing - Review \& Editing

Competing interests: No competing interests were disclosed.

Grant information: This review was supported by the Intramural Research Program of the National Institute of Allergy and Infectious Diseases/National Institutes of Health.

The funders had no role in study design, data collection and analysis, decision to publish, or preparation of the manuscript.

Copyright: ( 2018 Hawman DW and Feldmann H. This is an open access article distributed under the terms of the Creative Commons Attribution License, which permits unrestricted use, distribution, and reproduction in any medium, provided the original work is properly cited. The author(s) is/are employees of the US Government and therefore domestic copyright protection in USA does not apply to this work. The work may be protected under the copyright laws of other jurisdictions when used in those jurisdictions.

How to cite this article: Hawman DW and Feldmann $\mathrm{H}$. Recent advances in understanding Crimean-Congo hemorrhagic fever virus [version 1; peer review: 4 approved] F1000Research 2018, 7(F1000 Faculty Rev):1715

https://doi.org/10.12688/f1000research.16189.1

First published: 29 Oct 2018, 7(F1000 Faculty Rev):1715 https://doi.org/10.12688/f1000research.16189.1 


\section{Introduction}

Crimean-Congo hemorrhagic fever virus (CCHFV) is a negativesense RNA virus in the Nairoviridae family within the Bunyavirales order of viruses. CCHFV contains three genomic segments: small and medium, which encode for the nucleoprotein and glycoproteins, respectively, and a large segment encoding the RNA-dependent RNA-polymerase. CCHF as a disease was first described in humans in the 1940s when soldiers re-occupying abandoned farmland in the Crimea became ill with a hemorrhagic disease ${ }^{1}$. In the late 1960 s, it was discovered that the causative agent of this hemorrhagic disease in the Crimea was similar to the causative agent of hemorrhagic disease in the Belgian Congo (current Democratic Republic of the Congo) ${ }^{2}$, and the name "Crimean-Congo hemorrhagic fever virus" was ascribed to the pathogen. The main vector and reservoir of CCHFV are hard-body ticks principally of the Hyalomma genus, although there is limited evidence that other species of ticks such as Rhipicephalus and Dermacentor species may be vectors ${ }^{3}$. Vertebrate hosts such as domestic livestock and wild animals such as hares likely serve as amplifying hosts of CCHFV, with uninfected ticks becoming infected during feeding on viremic animals or during co-feeding with infected ticks ${ }^{4-6}$ (Figure 1). The Hyalomma vector is found throughout Africa, Southern and Eastern Europe, the Middle East, India, and Asia and cases of $\mathrm{CCHF}$ are reported throughout these regions ${ }^{7}$; an estimated 10,000 to 15,000 human infections with CCHFV occur each year, although most of these are subclinical and unrecognized ${ }^{7}$. In correlation with the extensive geographic distribution of CCHFV, CCHFV exhibits substantial genetic diversity among geographically distinct isolates; isolates differ at the amino acid level by $5 \%$ in the nucleoprotein and L protein and up to $25 \%$ in the glycoprotein precursor ${ }^{3}$.

\section{Disease and diagnosis}

Humans can become infected with CCHFV via tick bites and butchering of infected livestock and in the health-care setting during the care of infected patients ${ }^{8}$ (Figure 1). Following an incubation period of a few days, the initial symptoms of CCHF are a non-specific febrile illness that can occur suddenly. Sudden onset of fever, myalgia, diarrhea, nausea, and vomiting is typically reported. After this, patients enter the hemorrhagic period in which they begin exhibiting hemorrhages at various sites around the body ${ }^{8}$. Case fatality rates can differ between outbreaks but typically range from $5 \%$ to $30 \%{ }^{3}$. However, subclinical or mild cases of CCHF may go unnoticed and may represent a substantial portion of CCHFV infections in humans ${ }^{9}$. Despite the known genetic diversity of CCHFV, whether the infecting strain of CCHFV influences disease severity and outcome is unknown. High viral loads, absence of early antibody responses, and high levels of alanine aminotransferase (ALT) and aspartate aminotransferase (AST) are common predictors of poor outcome $\mathrm{e}^{10-14}$ (Figure 1). Thrombocytopenia and prolonged clotting times are also seen in severe cases ${ }^{12,14,15}$. Levels of inflammatory cytokines are elevated in severe and fatal $\mathrm{CCHF}$ cases $^{16-19}$, suggesting that CCHFV infection induces an inflammatory immune response.

The diagnosis of suspected CCHF cases can be accomplished by using reverse transcription-quantitative polymerase chain

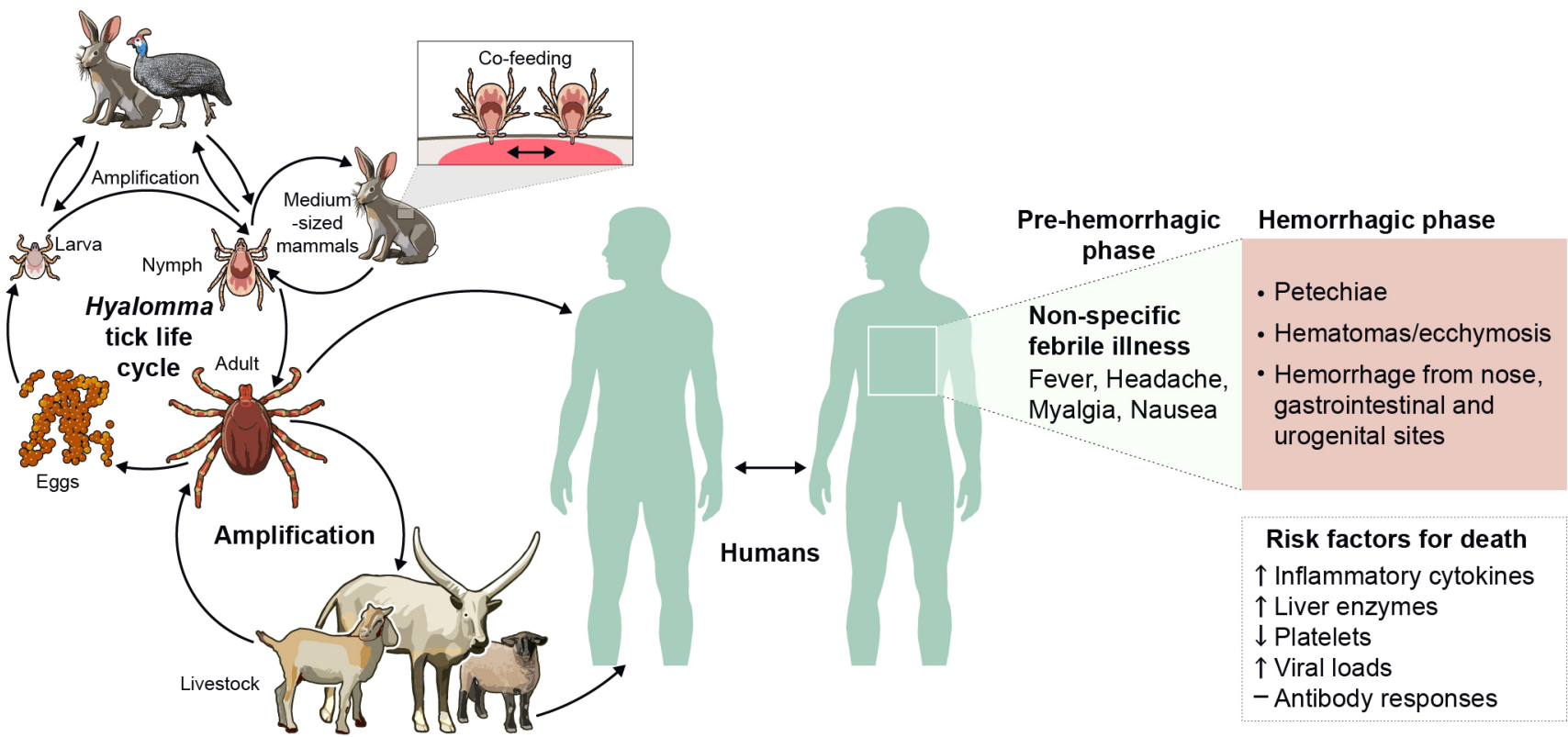

Figure 1. Crimean-Congo hemorrhagic fever virus (CCHFV). The natural reservoir and vector for CCHFV are ticks of the Hyalomma genus. Ticks can become infected at any life-cycle stage during feeding on a viremic animal or during co-feeding with an infected tick, and mammals likely act as important amplification hosts for the virus. Humans are at risk of CCHFV infection from tick bites, animal husbandry, and butchering of infected livestock and during the care of patients with CCHF. In humans, CCHF first presents as a non-specific febrile illness with a sudden onset of fever, headache, myalgia, and nausea. The disease can rapidly progress to the hemorrhagic phase of disease, during which patients exhibit petechiae, hematomas/ecchymosis, and hemorrhages from various sites around the body. Risk factors for death include elevated inflammatory cytokines and liver enzymes, high viral loads, decreased platelets, and absent antibody responses. 
reaction (RT-qPCR) during the viremic phase of disease. RTqPCR can also determine viral load, which often is correlated with disease outcome. An important consideration for these assays is the substantial genetic diversity of CCHFV; however, assays that can recognize a multitude of CCHFV genotypes have been developed ${ }^{20-22}$. Enzyme-linked immunosorbent assay and indirect immunofluorescent assay for the detection of human IgM and IgG CCHFV-specific antibodies are approaches of choice for serological diagnosis, and commercial kits are available. These tests may not be appropriate for suspected cases early during the acute phase of disease, as antibody responses are often absent or delayed in serious CCHF cases.

\section{Pathogenesis}

Curiously, extensive serological evidence indicates that CCHFV can productively infect numerous vertebrate species, including both wild and domestic animals, yet humans seem to be uniquely susceptible to severe or lethal disease. Even within humans, CCHFV infection may result in a mild or subclinical infection ${ }^{9}$, and why some patients develop a serious or fatal disease whereas others develop an asymptomatic infection is unknown.

The ability of CCHFV to cause severe or lethal disease in mice deficient in the type I interferon system but not wild-type (WT) mice $^{23-25}$ suggests that innate immune responses in vertebrate hosts play a substantial role in limiting CCHFV pathogenesis. In vitro studies have identified retinoic acid-inducible gene I (RIG-I) as an innate immune sensor of $\mathrm{CCHFV}^{26}$, although CCHFV may process its viral RNA to avoid RIG-I sensing ${ }^{27}$. However, it is likely that more innate immune sensors contribute to sensing of CCHFV. Retrospective studies in humans have identified correlates between polymorphisms in Toll-like receptors (TLRs) and severity of disease, suggesting that TLRs may be an important immune-sensing pathway in the control of CCHFV. Polymorphisms in TLR7, 8, 9, and 10 have been found to be correlated with disease severity and outcome in infected patients in Turkey $^{28-30}$. Polymorphisms in nuclear factor-kappa B have also been found to correlate with an increased risk of $\mathrm{CCHF}^{31}$. Whether similar polymorphisms are associated with CCHF and case severity in populations in other geographic regions remains to be determined. Host apoptotic pathways may restrict CCHFV replication, as CCHFV replication can induce apoptosis ${ }^{32,33}$, and caspase 3, activated during apoptosis, can cleave the CCHFV nucleoprotein and inhibit viral replication ${ }^{34,35}$.

CCHFV also antagonizes innate immune signaling. The L segment of CCHFV encodes an ovarian tumor-like deubiquitinase (OTU) domain that recently has been shown to suppress innate immune responses likely by deubiquitinating proteins involved in innate immune signaling pathways ${ }^{36}$. The CCHFV OTU domain can also cleave interferon-stimulated gene 15 (ISG15) modifications ${ }^{37,38}$. As ISG15 modifications have been implicated in direct antiviral effects and as ISG15 itself has been found to regulate the host innate immune response to viral infection ${ }^{39}$, the de-ISGylation activity of the CCHFV OTU domain may be important for viral pathogenesis. Recombinant CCHFV encoding an OTU deficient in deubiquitinase activity or deficient in both deubiquitinase and de-ISGylation activity had reduced viral growth kinetics compared with WT CCHFV in interferon-competent but not interferon-incompetent cells, demonstrating that the OTU domain is important in overcoming interferon responses ${ }^{36}$. Intriguingly, the CCHFV OTU domain has reduced affinity for mouse ISG15 compared with human ISG15, suggesting that mouse ISG15 may be an important barrier to CCHFV infection of mice $^{40,41}$. The CCHFV OTU domain also has higher affinity for human ISG15 than the OTU domains of related Nairoviridae members that are not associated with disease as severe as CCHF, suggesting that the OTU domain may be an important virulence factor for $\mathrm{CCHFV}^{40}$.

The role for adaptive immune responses against CCHFV in human pathogenesis is less clear. Low-to-absent anti-CCHFV antibody responses have been found to correlate with severe disease and death ${ }^{12-14}$, and levels of antibody may serve as a predictor of disease outcome. However, whether antibody responses contribute to the control of primary CCHFV infection is unknown, and neutralizing antibody responses even in survivors are typically low $^{13}$. Epitope mapping using linear peptides and serum from CCHFV survivors in Turkey and South Africa identified antibody responses toward epitopes in the mucin-like domain, GP38, and $\mathrm{Gn}$ protein $^{42}$ regions that are not likely to result in neutralizing antibodies ${ }^{43}$. However, non-neutralizing antibodies were protective against lethal CCHFV challenge ${ }^{43}$, demonstrating that antibodies can be protective via mechanisms other than neutralization. Studies evaluating a modified vaccinia virus-based vaccine for CCHFV found protection to require both cellular and humoral responses, suggesting that $\mathrm{T}$ cells may be an important component of vaccine-mediated protection against $\mathrm{CCHFV}^{44,45}$. The role for $\mathrm{T}$ cells in controlling primary CCHFV infection is unclear. Levels of circulating $\mathrm{CD}^{+}{ }^{+} \mathrm{CD} 8^{+} \mathrm{T}$ cells in peripheral blood were found to positively correlate with fatal outcome ${ }^{46}$, and human CCHF survivors have been shown to exhibit long-lived $\mathrm{CD}^{+} \mathrm{T}$-cell responses to $\mathrm{CCHFV}^{47}$. Human leukocyte antigen alleles have also been found to correlate with protection and susceptibility to $\mathrm{CCHFV}^{48}$. A humanized mouse model of CCHFV demonstrated that $\mathrm{T}$ cells were activated following $\mathrm{CCHFV}$ infection and $\mathrm{CD} 8^{+}$ $\mathrm{T}$ cells had elevated levels of perforin, a marker of cytolytic activity ${ }^{49}$. However, further studies are needed to understand how T-cell responses contribute to resolution of the infection.

Understanding the role of the adaptive immune response in the control of primary CCHFV infection has been limited by the lack of suitable animal models. Type I interferon-deficient mice exhibit a rapid-onset lethal disease prior to the development of adaptive immune responses, limiting the suitability of this model for studying adaptive immune responses. However, studies in STAT1-deficient mice demonstrated early activation of $\mathrm{CD}^{+}$and $\mathrm{CD}^{+} \mathrm{T}$ cells, although these cells were depleted from the spleen by day 3 post-infection (PI) and mice succumbed prior to detectable antibody responses ${ }^{25}$. In a recent study using mice treated with an interferon blockade antibody, mice deficient in adaptive immune responses, but not WT mice, supported persistent viral replication for at least 2 weeks PI, demonstrating that adaptive immune responses can control CCHFV in mice ${ }^{50}$. This model also demonstrated that adaptive 
immune responses, such as cytolytic T-cell activity, were not necessary for hepatic injury following CCHFV infection ${ }^{50}$. These data suggest that CCHFV is directly capable of causing liver damage independent of the host adaptive immune response's attempts to control viral replication. Furthermore, the recent development of a cynomolgus macaque model of $\mathrm{CCHF}^{51}$ may provide insight into the role of the adaptive immune response and disease outcome. In this model, neither antibody titers nor neutralizing activity of the antibodies correlated with disease outcome $^{51}$. However, studies evaluating the contribution of the T-cell response to disease outcome in this model are still needed.

\section{Animal models}

For many decades after the discovery and isolation of CCHFV, intracerebrally inoculated neonatal mice were used to propagate and detect CCHFV, as many other commonly used laboratory animals showed no disease following inoculation ${ }^{52}$. Currently, the standard mouse model uses mice deficient in type I or both type I and type II interferon responses ${ }^{23-25}$ (Table 1). Interferondeficient mice typically exhibit a sudden onset of severe disease followed by death within 4 days PI, and mice exhibit high levels of inflammatory cytokines and elevated liver enzymes at time of death, similar to human CCHFV infections ${ }^{23-25,53}$. Our lab recently described, in contrast to the sudden onset and death of CCHFV-infected mice in previous models, a model in which type I interferon-deficient mice infected with a clinical isolate, strain Hoti, develop a progressively worsening disease with several days of overt clinical signs followed by death at around day 7 or $8^{54}$. Similarly, low-dose challenge of mice with the clinical isolate Turkey-Kelkit06 strain resulted in a protracted but ultimately fatal disease ${ }^{55}$. However, clinical isolates are capable of causing rapidly fatal disease in these mice as demonstrated for the Afg-09 $\operatorname{strain}^{53}$. These distinct disease progressions of different CCHFV strains in mice suggest that there are important virulence determinants within CCHFV that remain to be described. Furthermore, a mouse model using the interferon blockade antibody MAR1-5A3 has been developed, allowing transient blockade of interferon signaling in a variety of mouse genetic backgrounds ${ }^{50,56}$. This model also allows the vaccination of fully immunocompetent animals that are rendered interferon deficient only at the time of CCHFV challenge, which may improve immune responses to certain vaccines $^{56}$.

Recently, a humanized mouse model was described for $\mathrm{CCHFV}^{49}$. In this model, irradiated mice are engrafted with human $\mathrm{CD}_{3}{ }^{+}$ hematopoietic stem cells. This model identified strain-specific virulence with humanized mice infected with a Turkey strain of CCHFV succumbing 2 to 3 weeks PI, whereas mice infected with an Oman strain survived until the study endpoint ${ }^{49}$. Interestingly, the mice euthanized for terminal disease following CCHFV Turkey infection were euthanized for neurological manifestations, and high viral loads were found in the brains of euthanized mice ${ }^{49}$ (Table 1).

Until recently, there existed no immunocompetent animal model for CCHF. However, our lab recently described a cynomolgus macaque model of $\mathrm{CCHF}$ in which cynomolgus macaques infected with a human clinical isolate of CCHFV, strain Hoti, recapitulate many aspects of human $\mathrm{CCHF}$ cases $^{51}$ (Table 1). Infected macaques develop a spectrum of disease outcome similar to that of human $\mathrm{CCHF}$ cases from asymptomatic to severe or lethal infections. Infected animals developed an early viremia, elevated levels of inflammatory cytokines, thrombocytopenia, and elevated liver enzymes similar to those of human cases of CCHF. Histological analysis showed that CCHFV infection resulted mainly in pathological changes in the liver and spleen, and in situ hybridization demonstrated infection of hepatocytes, Kupffer cells, and endothelial cells of the liver and marginal zone lymphocytes of the spleen and lymph nodes. Although this model is not uniformly lethal, the spectrum of clinical outcome following CCHFV infection within this model provides an opportunity to identify the host and viral mechanisms that contribute to disease outcome.

The role of the tick reservoir in CCHFV pathogenesis in vertebrates is largely unknown ${ }^{57}$. Current animal studies use needle-delivered mammalian-cell culture-grown $\mathrm{CCHFV}$, which excludes any

Table 1. Animal models of Crimean-Congo hemorrhagic fever virus (CCHFV).

\begin{tabular}{|c|c|}
\hline Mice & Cyno \\
\hline 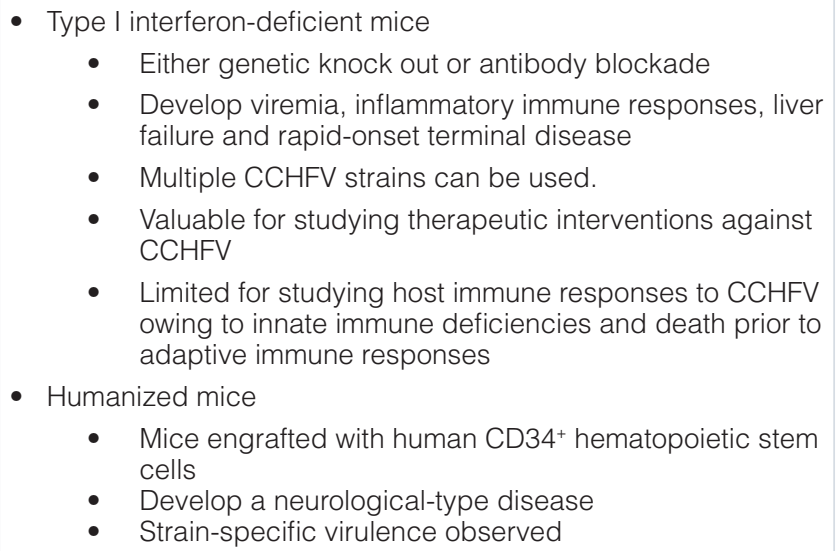 & $\begin{array}{l}\text { - Adult, immunocompetent macaques infected with } \\
\text { CCHFV strain Hoti } \\
\text { - Exhibit a spectrum of disease outcomes from } \\
\text { asymptomatic to severe, lethal disease } \\
\text { - Develop viremia, inflammatory immune responses, } \\
\text { elevated liver enzymes, and increased clotting } \\
\text { times } \\
\text { - Major sites of viral replication are liver and spleen } \\
\text { - Valuable pre-clinical model for therapeutic } \\
\text { interventions against CCHFV } \\
\text { - Can be used to study host and viral determinants } \\
\text { of disease outcome }\end{array}$ \\
\hline
\end{tabular}


contribution of tick-derived factors in these models. Tick saliva is capable of modulating a variety of early host defenses ${ }^{58}$ and may play a role in the early immune responses to $\mathrm{CCHFV}$, as tick saliva inhibited the migration of antigen-presenting cells in vitro ${ }^{59}$. A tick transmission model involving infected ticks feeding on mice has recently shown that CCHFV genetic diversity may be shaped by the tick reservoir rather than the vertebrate hosts $^{60}$.

\section{Vaccines}

Currently, the only vaccine for CCHFV is an inactivated preparation of virus grown in neonatal mouse brains ${ }^{61,62}$; however, this vaccine is used only in Bulgaria and is not approved for use in other countries with at-risk populations. The scalability and safety concerns of this type of vaccine will likely prevent widespread deployment of this vaccine, and new vaccine platforms for $\mathrm{CCHFV}$ are needed. An international collaboration among CCHFV researchers has been started to develop CCHFV vaccines and bring them to the clinic (http://www.cchfvaccine. $\mathrm{eu} /$ ), and several vaccines have shown promise in pre-clinical trials. A modified vaccinia virus expressing the glycoproteins of CCHFV was shown to provide $100 \%$ protection to lethally challenged mice ${ }^{44}$. DNA-based vaccination or virus-like particle vaccination has also been shown to confer protection against lethal CCHFV challenge ${ }^{56,63}$. Mice fed transgenic plants expressing the CCHFV glycoproteins developed antibodies against the glycoproteins ${ }^{64}$, although the efficacy of this platform against CCHFV challenge was not tested. Interestingly, although subunit vaccines containing the glycoproteins are immunogenic in mice ${ }^{65,66}$, they may not induce protective immune responses to $\mathrm{CCHFV}$ challenge ${ }^{65}$. A formalin-inactivated preparation of CCHFV was also found to be protective against CCHFV infection in mice ${ }^{55}$.

In addition to the glycoproteins, the nucleoprotein of CCHFV, encoded by the $\mathrm{S}$ segment, has been targeted by vaccines either on its own $^{67,68}$ or in combination platforms that include both the nucleoprotein and the glycoproteins ${ }^{63}$. Notably, vaccination with an adenovirus expressing the nucleoprotein of CCHFV provided substantial protection against lethal CCHFV challenge in mice ${ }^{67}$, demonstrating that immune responses directed against the nucleoprotein can be protective independently of responses to the glycoproteins. However, a modified vaccinia virus expressing the nucleoprotein of CCHFV, though immunogenic, failed to protect against lethal CCHFV challenge ${ }^{68}$, suggesting that protection afforded by nucleoprotein-based vaccines may be incomplete. Nevertheless, the greater sequence conservation of the nucleoprotein, even among divergent CCHFV strains, suggests that the nucleoprotein may be worth including in vaccine preparations to generate broadly protective immune responses.

\section{Antivirals}

In addition to vaccines, investigations of antivirals against CCHFV have been conducted. Ribavirin, a nucleoside analog, is suggested by the World Health Organization for the treatment of CCHFV. However, clinical data supporting the use of ribavirin to treat CCHF are inconsistent; some studies report benefits whereas others report no benefit, and meta-analyses of multiple studies suggest that the efficacy of ribavirin is poor or inconclusive ${ }^{69-71}$. Notably, a placebo-controlled study failed to identify a clinical benefit of ribavirin treatment in patients with $\mathrm{CCHF}^{72}$. A recent meta-analysis demonstrated that ribavirin treatment needs to be started soon after symptom onset ( $<48$ hours) to reduce odds of death ${ }^{73}$. In the recent emergence of CCHFV in Spain, although treatment of an infected nurse with ribavirin had mutagenic effects on CCHFV in vivo and a reduction in viral titers was coincident with treatment $\operatorname{start}^{74}$, ultimately ribavirin treatment was discontinued because of suspected hemolytic anemia ${ }^{75}$, a potential complication of ribavirin treatment ${ }^{76,77}$. The inconsistent data on the clinical benefit of ribavirin for the treatment of CCHFV and the potential for adverse events with ribavirin treatment have caused significant debate in the field ${ }^{78-81}$. Ethical considerations of placebo-controlled studies will likely make further studies of this type difficult ${ }^{82}$, preventing definitive conclusions on the efficacy of ribavirin in patients with CCHF.

Studies in mouse models have also shown inconsistent efficacy of ribavirin. Two studies have shown that even early treatment with ribavirin $(<6$ hours PI) was unable to prevent lethal disease following infection with two distinct clinical isolates of $\mathrm{CCHFV}^{53,54}$. However, another study showed that ribavirin could protect against lethal disease following CCHFV strain 10200 infection when administered early and that protection diminished when treatment was delayed or challenge dose was increased ${ }^{25}$. However, results from our lab showed that although early ribavirin treatment extended the mean time to death, ribavirin was unable to prevent death in 10200 -infected mice ${ }^{54}$. The reason for the distinct outcomes in ribavirin-treated strain 10200-infected mice seen between our study ${ }^{54}$ and that by Bente et al..$^{25}$ is unknown but could be due to differences in mouse strain (IFNAR $^{-/-}$versus STAT1 ${ }^{-/}$), challenge dose, or the time treatment was started after infection. Cumulatively, data in humans and mice suggest that while ribavirin may have limited clinical benefit in patients with CCHF, treatment likely needs to be started early in the course of disease to have clinical benefit. This may prove difficult, as the early symptoms of CCHF are non-specific and can progress rapidly to severe, hemorrhagic manifestations ${ }^{8}$ and therefore patients may not present to healthcare providers until exhibiting the more serious symptoms of CCHF.

Favipiravir is approved in Japan for the treatment of influenza virus infections ${ }^{83}$ but has shown promise against other highly pathogenic RNA viruses, including Ebola ${ }^{84}$ and Lassa ${ }^{85,86}$. Two studies have evaluated favipiravir against CCHFV in vivo. In a study by Oestereich et al., favipiravir treatment was effective in suppressing viral replication and preventing mortality following CCHFV infection, even when treatment was started 48 hours PI $^{53}$. Similarly, work by our group has shown that favipiravir treatment could be delayed until 6 days PI, a time point at which mice were exhibiting advanced disease, including death, and still offer significant clinical benefit to CCHFV-infected mice ${ }^{54}$. These data suggest that favipiravir may be an effective antiviral for the treatment of advanced CCHF. Furthermore, Oestereich et al. demonstrated that favipiravir and ribavirin could synergistically 
inhibit CCHFV in vitro, allowing lower doses of both drugs to be used in vivo with clinical efficacy, suggesting that combination therapies in humans may be effective in treating CCHF while reducing unwanted side effects ${ }^{53}$. A similar approach has been used in Lassa fever cases ${ }^{87}$. In addition, a highthroughput screen using recombinant CCHFV identified a compound, 2'-deoxy-2'-fluorocytidine, with inhibitory activity superior to that of favipiravir or ribavirin in vitro ${ }^{88}$. In vivo animal studies will be needed to evaluate how this compound performs in animal models of CCHF. Lastly, monoclonal antibodies have shown efficacy against CCHFV in vivo ${ }^{43}$, and several clones were shown to neutralize divergent CCHFV strains ${ }^{89}$, suggesting that they may have promise for the treatment of CCHF.

\section{Summary}

In conclusion, much remains to be understood about the pathogenesis of CCHFV. However, the toolset for studying CCHFV has been steadily improving in recent years with the development of mouse and non-human primate models to a reverse genetics system for CCHFV that will facilitate dissection of the host and viral determinants of CCHFV pathogenesis. These tools will also allow the development and evaluation of novel therapies that reduce or prevent CCHFV-induced morbidity and mortality. Hopefully, the collaboration of multiple institutions in countries around the world toward the development of vaccines against CCHFV will lead to safe and effective vaccines for CCHFV being deployed in populations at risk for $\mathrm{CCHFV}$ infection. Lastly, the role of the tick vector in transmission and pathogenesis needs more attention, as does the role of livestock and other animal species in maintaining and transmitting CCHFV. This could lead to more effective measures to block CCHFV transmission.

\section{Grant information}

This review was supported by the Intramural Research Program of the National Institute of Allergy and Infectious Diseases/ National Institutes of Health.

The funders had no role in study design, data collection and analysis, decision to publish, or preparation of the manuscript.
1. Hoogstraal $\mathrm{H}$ : The epidemiology of tick-borne Crimean-Congo hemorrhagic fever in Asia, Europe, and Africa. J Med Entomol. 1979; 15(4): 307-417. PubMed Abstract | Publisher Full Text

2. Casals J: Antigenic similarity between the virus causing Crimean hemorrhagic fever and Congo virus. Proc Soc Exp Biol Med. 1969; 131(1): 233-6. PubMed Abstract | Publisher Full Text

3. F Bente DA, Forrester NL, Watts DM, et al:: Crimean-Congo hemorrhagic fever: history, epidemiology, pathogenesis, clinical syndrome and genetic diversity. Antiviral Res. 2013; 100(1): 159-89. PubMed Abstract | Publisher Full Text | F1000 Recommendation

4. $\quad \mathrm{F}$ Gargili A, Estrada-Peña A, Spengler JR, et al.: The role of ticks in the maintenance and transmission of Crimean-Congo hemorrhagic fever virus: A review of published field and laboratory studies. Antiviral Res. 2017; 144: 93-119.

PubMed Abstract | Publisher Full Text | Free Full Text | F1000 Recommendation

5. F Spengler JR, Bergeron É, Rollin PE: Seroepidemiological Studies of Crimean-Congo Hemorrhagic Fever Virus in Domestic and Wild Animals. PLOS Negl Trop Dis. 2016; 10(1): e0004210.

PubMed Abstract | Publisher Full Text | Free Full Text | F1000 Recommendation

6. Gordon SW, Linthicum KJ, Moulton JR: Transmission of Crimean-Congo hemorrhagic fever virus in two species of Hyalomma ticks from infected adults to cofeeding immature forms. Am J Trop Med Hyg. 1993; 48(4): 576-80. PubMed Abstract | Publisher Full Text

7. Crimean-Congo haemorrhagic fever. 2017. Reference Source

8. Ergönül O: Crimean-Congo haemorrhagic fever. Lancet Infect Dis. 2006; 6(4): 203-14.

PubMed Abstract | Publisher Full Text

9. $\mathrm{F}$ Bodur $\mathrm{H}$, Akinci $\mathrm{E}$, Ascioglu $\mathrm{S}$, et al:: Subclinical infections with CrimeanCongo hemorrhagic fever virus, Turkey. Emerg Infect Dis. 2012; 18(4): 640-2. PubMed Abstract | Publisher Full Text | Free Full Text | F1000 Recommendation

10. F Hasanoglu I, Guner R, Carhan A, et al:: Crucial parameter of the outcome in Crimean Congo hemorrhagic fever: Viral load. J Clin Virol. 2016; 75: 42-6. PubMed Abstract | Publisher Full Text | F1000 Recommendation

11. Duh D, Saksida A, Petrovec M, et al:: Viral load as predictor of Crimean-Congo hemorrhagic fever outcome. Emerg Infect Dis. 2007; 13(11): 1769-72. PubMed Abstract | Publisher Full Text | Free Full Text

12. Ergonul O, Celikbas A, Baykam N, et al:: Analysis of risk-factors among patients with Crimean-Congo haemorrhagic fever virus infection: Severity criteria revisited. Clin Microbiol Infect. 2006; 12(6): 551-4. PubMed Abstract | Publisher Full Text

13. Shepherd AJ, Swanepoel R, Leman PA: Antibody response in Crimean-Congo hemorrhagic fever. Rev Infect Dis. 1989; 11 Suppl 4: S801-S806. PubMed Abstract | Publisher Full Text

14. Swanepoel R, Gill DE, Shepherd AJ, et al.: The clinical pathology of CrimeanCongo hemorrhagic fever. Rev Infect Dis. 1989; 11 Suppl 4: S794-S800. PubMed Abstract | Publisher Full Text

15. Cevik MA, Erbay A, Bodur $\mathrm{H}$, et al:: Clinical and laboratory features of Crimean Congo hemorrhagic fever: predictors of fatality. Int J Infect Dis. 2008; 12(4): 374-9.

PubMed Abstract | Publisher Full Text

16. Ergonul O, Tuncbilek S, Baykam N, et al:: Evaluation of serum levels of interleukin (IL)-6, IL-10, and tumor necrosis factor-alpha in patients with Crimean-Congo hemorrhagic fever. J Infect Dis. 2006; 193(7): 941-4. PubMed Abstract | Publisher Full Text

17. Papa A, Bino S, Velo E, et al:: Cytokine levels in Crimean-Congo hemorrhagic fever. J Clin Virol. 2006; 36(4): 272-6.

PubMed Abstract | Publisher Full Text

18. Kaya S, Elaldi N, Kubar A, et al:: Sequential determination of serum viral titers, virus-specific IgG antibodies, and TNF- $\alpha$, IL-6, IL-10, and IFN- $\gamma$ levels in patients with Crimean-Congo hemorrhagic fever. BMC Infect Dis. 2014; 14: 416. PubMed Abstract | Publisher Full Text | Free Full Text

19. F Papa A, Tsergouli K, Çağlayık DY, et al.: Cytokines as biomarkers of Crimean-Congo hemorrhagic fever. J Med Virol. 2016; 88(1): 21-7. PubMed Abstract | Publisher Full Text | F1000 Recommendation

20. Sas MA, Vina-Rodriguez A, Mertens M, et al:: A one-step multiplex real-time RT-PCR for the universal detection of all currently known CCHFV genotypes. $J$ Virol Methods. 2018; 255: 38-43. PubMed Abstract | Publisher Full Text

21. Atkinson B, Chamberlain J, Logue $\mathrm{CH}$, et al:: Development of a real-time RT-PCR assay for the detection of Crimean-Congo hemorrhagic fever virus. Vector Borne Zoonotic Dis. 2012; 12(9): 786-93. PubMed Abstract | Publisher Full Text

22. Jääskeläinen $\mathrm{AJ}$, Kallio-Kokko $\mathrm{H}$, Ozkul $\mathrm{A}$, et al.: Development and evaluation of a real-time RT-qPCR for detection of Crimean-Congo hemorrhagic fever virus representing different genotypes. Vector Borne Zoonotic Dis. 2014; 14(12): $870-2$.

PubMed Abstract | Publisher Full Text | Free Full Text

23. Zivcec M, Safronetz D, Scott D, et al.: Lethal Crimean-Congo hemorrhagic fever 
virus infection in interferon $\alpha / \beta$ receptor knockout mice is associated with high viral loads, proinflammatory responses, and coagulopathy. J Infect Dis. 2013; 207(12): 1909-21.

PubMed Abstract | Publisher Full Text | Free Full Text

24. Bereczky S, Lindegren $\mathrm{G}$, Karlberg $\mathrm{H}$, et al.: Crimean-Congo hemorrhagic fever virus infection is lethal for adult type I interferon receptor-knockout mice. $J$ Gen Virol. 2010; 91(Pt 6): 1473-7.

PubMed Abstract | Publisher Full Text

25. Bente DA, Alimonti JB, Shieh WJ, et al:: Pathogenesis and immune response of Crimean-Congo hemorrhagic fever virus in a STAT-1 knockout mouse model. $J$ Virol. 2010; 84(21): 11089-100

PubMed Abstract | Publisher Full Text | Free Full Text

26. Spengler JR, Patel JR, Chakrabarti AK, et al.: RIG-I Mediates an Antiviral Response to Crimean-Congo Hemorrhagic Fever Virus. J Virol. 2015; 89(20): 10219-29.

PubMed Abstract | Publisher Full Text | Free Full Text

27. F Habjan M, Andersson I, Klingström J, et al.: Processing of genome 5' termini as a strategy of negative-strand RNA viruses to avoid RIG-I-dependent interferon induction. PLoS One. 2008; 3(4): e2032.

PubMed Abstract | Publisher Full Text | Free Full Text | F1000 Recommendation

28. Arslan S, Engin A, Özbilüm N, et al:: Toll-like receptor 7 Gln11Leu, c.4-151A/G and $+1817 \mathrm{G} / \mathrm{T}$ polymorphisms in Crimean Congo hemorrhagic fever. $J \mathrm{Med}$ Virol. 2015; 87(7): 1090-5.

PubMed Abstract | Publisher Full Text

29. Engin A, Arslan S, Kizildag S, et al:: Toll-like receptor 8 and 9 polymorphisms in Crimean-Congo hemorrhagic fever. Microbes Infect. 2010; 12(12-13): 1071-8. PubMed Abstract | Publisher Full Text

30. Kızıldağ S, Arslan S, Özbilüm N, et al:: Effect of TLR10 (2322A/G, 720A/C, and 992T/A) polymorphisms on the pathogenesis of Crimean Congo hemorrhagic fever disease. J Med Virol. 2018; 90(1): 19-25.

PubMed Abstract | Publisher Full Text

31. Arslan S, Engin A: Relationship between NF-кB1 and NF-кBIA genetic polymorphisms and Crimean-Congo hemorrhagic fever. Scand $J$ Infect Dis. 2012; 44(2): 138-43.

PubMed Abstract | Publisher Full Text

32. F Barnwal B, Karlberg H, Mirazimi A, et al.: The Non-structural Protein of Crimean-Congo Hemorrhagic Fever Virus Disrupts the Mitochondria Membrane Potential and Induces Apoptosis. J Biol Chem. 2016; 291(2): 582-92. PubMed Abstract | Publisher Full Text | Free Full Text | F1000 Recommendation

33. Rodrigues R, Paranhos-Baccalà G, Vernet G, et al:: Crimean-Congo hemorrhagic fever virus-infected hepatocytes induce ER-stress and apoptosis crosstalk. PLoS One. 2012; 7(1): e29712.

PubMed Abstract | Publisher Full Text | Free Full Text

34. Karlberg H, Tan YJ, Mirazimi A: Induction of caspase activation and cleavage of the viral nucleocapsid protein in different cell types during Crimean-Congo hemorrhagic fever virus infection. J Biol Chem. 2011; 286(5): 3227-34 PubMed Abstract | Publisher Full Text | Free Full Text

35. Wang $\mathrm{Y}$, Dutta $\mathrm{S}$, Karlberg $\mathrm{H}$, et al:: Structure of Crimean-Congo hemorrhagic fever virus nucleoprotein: superhelical homo-oligomers and the role of caspase-3 cleavage. J Virol. 2012; 86(22): 12294-303. PubMed Abstract | Publisher Full Text | Free Full Text

36. F Scholte FEM, Zivcec M, Dzimianski JV, et al:: Crimean-Congo Hemorrhagic Fever Virus Suppresses Innate Immune Responses via a Ubiquitin and ISG15 Specific Protease. Cell Rep. 2017; 20(10): 2396-407.

PubMed Abstract | Publisher Full Text | Free Full Text | F1000 Recommendation

37. F Frias-Staheli N, Giannakopoulos NV, Kikkert M, et al:: Ovarian tumor domain containing viral proteases evade ubiquitin- and ISG15-dependent innate immune responses. Cell Host Microbe. 2007; 2(6): 404-16.

PubMed Abstract | Publisher Full Text | Free Full Text | F1000 Recommendation

38. James TW, Frias-Staheli N, Bacik JP, et al:: Structural basis for the removal of ubiquitin and interferon-stimulated gene 15 by a viral ovarian tumor domaincontaining protease. Proc Natl Acad Sci U S A. 2011; 108(6): 2222-7. PubMed Abstract | Publisher Full Text | Free Full Text

39. F Perng YC, Lenschow DJ: ISG15 in antiviral immunity and beyond. Nat Rev Microbiol. 2018; 16(7): 423-39.

PubMed Abstract | Publisher Full Text | F1000 Recommendation

40. Capodagli GC, Deaton MK, Baker EA, et al.: Diversity of ubiquitin and ISG15 specificity among nairoviruses' viral ovarian tumor domain proteases. $J$ Virol. 2013; 87(7): 3815-27.

PubMed Abstract | Publisher Full Text | Free Full Text

41. F Deaton MK, Dzimianski JV, Daczkowski CM, et al.: Biochemical and Structural Insights into the Preference of Nairoviral DelSGylases for Interferon-Stimulated Gene Product 15 Originating from Certain Species. J Virol. 2016; 90(18): 8314-27.

PubMed Abstract | Publisher Full Text | Free Full Text | F1000 Recommendation

42. Fritzen A, Risinger C, Korukluoglu G, et al.: Epitope-mapping of the glycoprotein from Crimean-Congo hemorrhagic fever virus using a microarray approach. PLoS Negl Trop Dis. 2018; 12(7): e0006598.

PubMed Abstract | Publisher Full Text | Free Full Text

43. Bertolotti-Ciarlet A, Smith J, Strecker K, et al:: Cellular localization and antigenic characterization of crimean-congo hemorrhagic fever virus glycoproteins.
J Virol. 2005; 79(10): 6152-61.

PubMed Abstract | Publisher Full Text | Free Full Text

44. Buttigieg KR, Dowall SD, Findlay-Wilson S, et al: A novel vaccine against Crimean-Congo Haemorrhagic Fever protects $100 \%$ of animals against lethal challenge in a mouse model. PLOS One. 2014; 9(3): e91516. PubMed Abstract | Publisher Full Text | Free Full Text

45. F Dowall SD, Graham VA, Rayner E, et al:: Protective effects of a Modified Vaccinia Ankara-based vaccine candidate against Crimean-Congo Haemorrhagic Fever virus require both cellular and humoral responses. PLOS One. 2016; 11(6): e0156637.

PubMed Abstract | Publisher Full Text | Free Full Text | F1000 Recommendation

46. Akinci E, Yilmaz M, Bodur $\mathrm{H}$, et al.: Analysis of lymphocyte subgroups in Crimean-Congo hemorrhagic fever. Int J Infect Dis. 2009; 13(5): 560-3. PubMed Abstract | Publisher Full Text

47. F Goedhals D, Paweska JT, Burt FJ: Long-lived CD8+ T cell responses following Crimean-Congo haemorrhagic fever virus infection. PLOS Negl Trop Dis. 2017; 11(12): e0006149.

PubMed Abstract | Publisher Full Text | Free Full Text | F1000 Recommendation

48. Akıncı $\mathrm{E}$, Bodur $\mathrm{H}$, Muşabak $\mathrm{U}$, et al:: The relationship between the human leukocyte antigen system and Crimean-Congo hemorrhagic fever in the Turkish population. Int J Infect Dis. 2013; 17(11): e1038-41. PubMed Abstract | Publisher Full Text

49. F Spengler JR, Kelly Keating M, McElroy AK, et al.: Crimean-Conge Hemorrhagic Fever in Humanized Mice Reveals Glial Cells as Primary Targets of Neurological Infection. J Infect Dis. 2017; 216(11): 1386-97. PubMed Abstract | Publisher Full Text | Free Full Text | F1000 Recommendation

50. $\mathrm{F}$ Lindquist ME, Zeng $X$, Altamura LA, et al:: Exploring Crimean-Congo Hemorrhagic Fever Virus-Induced Hepatic Injury Using Antibody-Mediated Type I Interferon Blockade in Mice. J Virol. 2018; 92(21): pii: e01083-18. PubMed Abstract | Publisher Full Text | F1000 Recommendation

51. Haddock E, Feldmann F, Hawman DW, et al.: A cynomolgus macaque model for Crimean-Congo haemorrhagic fever. Nat Microbiol. 2018; 3(5): 556-62. PubMed Abstract | Publisher Full Text

52. Smirnova SE: A comparative study of the Crimean hemorrhagic fever-Congo group of viruses. Arch Virol. 1979; 62(2): 137-43. PubMled Abstract | Publisher Full Text

53. Oestereich L, Rieger T, Neumann M, et al: Evaluation of antiviral efficacy of ribavirin, arbidol, and T-705 (favipiravir) in a mouse model for Crimean-Congo hemorrhagic fever. PLoS Negl Trop Dis. 2014; 8(5): e2804. PubMed Abstract | Publisher Full Text | Free Full Text

54. Hawman DW, Haddock E, Meade-White K, et al: Favipiravir (T-705) but not ribavirin is effective against two distinct strains of Crimean-Congo hemorrhagic fever virus in mice. Antiviral Res. 2018; 157: 18-26. PubMled Abstract | Publisher Full Text

55. Canakoglu N, Berber E, Tonbak S, et al: Immunization of knock-out $\alpha / \beta$ interferon receptor mice against high lethal dose of Crimean-Congo hemorrhagic fever virus with a cell culture based vaccine. PLOS Negl Trop Dis. 2015; 9(3): e0003579.

PubMed Abstract | Publisher Full Text | Free Full Text

56. Garrison AR, Shoemaker CJ, Golden JW, et al: A DNA vaccine for CrimeanCongo hemorrhagic fever protects against disease and death in two lethal mouse models. PLOS Negl Trop Dis. 2017; 11(9): e0005908. PubMed Abstract | Publisher Full Text | Free Full Text

57. Papa A, Tsergouli K, Tsioka K, et al.: Crimean-Congo Hemorrhagic Fever: TickHost-Virus Interactions. Front Cell Infect Microbiol. 2017; 7: 213. PubMed Abstract | Publisher Full Text | Free Full Text

58. Šimo L, Kazimirova M, Richardson J, et al:: The Essential Role of Tick Salivary Glands and Saliva in Tick Feeding and Pathogen Transmission. Front Cell Infect Microbiol. 2017; 7: 281 .

PubMed Abstract | Publisher Full Text | Free Full Text

59. F Rodriguez SE, McAuley AJ, Gargili A, et al.: Interactions of Human Dermal Dendritic Cells and Langerhans Cells Treated with Hyalomma Tick Saliva with Crimean-Congo Hemorrhagic Fever Virus. Viruses. 2018; 10(7): pii: E381. PubMed Abstract | Publisher Full Text | Free Full Text | F1000 Recommendation

60. F Xia H, Beck AS, Gargili A, et al:: Transstadial Transmission and Long-term Association of Crimean-Congo Hemorrhagic Fever Virus in Ticks Shapes Genome Plasticity. Sci Rep. 2016; 6: 35819 .

PubMed Abstract | Publisher Full Text | Free Full Text | F1000 Recommendation

61. Mousavi-Jazi M, Karlberg H, Papa A, et al.: Healthy individuals' immune response to the Bulgarian Crimean-Congo hemorrhagic fever virus vaccine. Vaccine. 2012; 30(44): 6225-9. PubMed Abstract | Publisher Full Text

62. Papa A, Papadimitriou E, Christova I: The Bulgarian vaccine Crimean-Congo haemorrhagic fever virus strain. Scand J Infect Dis. 2011; 43(3): 225-9. PubMed Abstract| Publisher Full Text

63. F Hinkula J, Devignot S, Åkerström S, et al:: Immunization with DNA Plasmids Coding for Crimean-Congo Hemorrhagic Fever Virus Capsid and Envelope Proteins and/or Virus-Like Particles Induces Protection and Survival in Challenged Mice. J Virol. 2017; 91(10): pii: e02076-16. PubMed Abstract | Publisher Full Text | Free Full Text | F1000 Recommendation 
64. Ghiasi SM, Salmanian AH, Chinikar S, et al:: Mice orally immunized with a transgenic plant expressing the glycoprotein of Crimean-Congo hemorrhagic fever virus. Clin Vaccine Immunol. 2011; 18(12): 2031-7. PubMed Abstract | Publisher Full Text | Free Full Text

65. Kortekaas J, Vloet RP, McAuley AJ, et al:: Crimean-Congo Hemorrhagic Fever Virus Subunit Vaccines Induce High Levels of Neutralizing Antibodies But No Protection in STAT1 Knockout Mice. Vector Borne Zoonotic Dis. 2015; 15(12): 759-64.

PubMed Abstract | Publisher Full Text

66. Rahpeyma M, Samarbaf-Zadeh A, Makvandi M, et al.: Expression and characterization of codon-optimized Crimean-Congo hemorrhagic fever virus Gn glycoprotein in insect cells. Arch Virol. 2017; 162(7): 1951-62. PubMed Abstract | Publisher Full Text

67. Zivcec M, Safronetz D, Scott DP, et al:: Nucleocapsid protein-based vaccine provides protection in mice against lethal Crimean-Congo hemorrhagic fever virus challenge. PLoS Negl Trop Dis. 2018; 12(7): e0006628. PubMed Abstract | Publisher Full Text | Free Full Text

68. Dowall SD, Buttigieg KR, Findlay-Wilson SJ, et al:: A Crimean-Congo hemorrhagic fever (CCHF) viral vaccine expressing nucleoprotein is immunogenic but fails to confer protection against lethal disease. Hum Vaccin Immunother. 2016; 12(2): 519-27.

PubMed Abstract | Publisher Full Text | Free Full Text

69. Soares-Weiser K, Thomas S, Thomson G, et al.: Ribavirin for Crimean-Congo hemorrhagic fever: systematic review and meta-analysis. BMC Infect Dis. 2010; 10: 207.

PubMed Abstract | Publisher Full Text | Free Full Text

70. Ascioglu S, Leblebicioglu $\mathrm{H}$, Vahaboglu $\mathrm{H}$, et al.: Ribavirin for patients with Crimean-Congo haemorrhagic fever: a systematic review and meta-analysis. $J$ Antimicrob Chemother. 2011; 66(6): 1215-22.

PubMed Abstract | Publisher Full Text

71. Johnson S, Henschke N, Maayan N, et al:: Ribavirin for treating Crimean Congo haemorrhagic fever. Cochrane Database Syst Rev. 2018; 6: CD012713. PubMed Abstract | Publisher Full Text | Free Full Text

72. F Koksal I, Yilmaz G, Aksoy F, et al.: The efficacy of ribavirin in the treatment of Crimean-Congo hemorrhagic fever in Eastern Black Sea region in Turkey. J Clin Virol. 2010; 47(1): 65-8. PubMed Abstract | Publisher Full Text | F1000 Recommendation

73. F Ergönül Ö, Keske Ş, Çeldir MG, et al: Systematic Review and Meta-analysis of Postexposure Prophylaxis for Crimean-Congo Hemorrhagic Fever Virus among Healthcare Workers. Emerg Infect Dis. 2018; 24(9): 1642-8. PubMed Abstract | Publisher Full Text | Free Full Text | F1000 Recommendation

74. F Espy N, Pérez-Sautu U, Ramírez de Arellano E, et al:: Ribavirin Had Demonstrable Effects on the Crimean-Congo Hemorrhagic Fever Virus (CCHFV) Population and Load in a Patient With CCHF Infection. J Infect Dis. 2018; 217(12): 1952-6.

PubMed Abstract | Publisher Full Text | F1000 Recommendation

75. Negredo A, de la Calle-Prieto F, Palencia-Herrejón E, et al:: Autochthonous Crimean-Congo Hemorrhagic Fever in Spain. N Engl J Med. 2017; 377(2): 154-61. PubMed Abstract | Publisher Full Text

76. Muller MP, Dresser L, Raboud J, et al:: Adverse events associated with highdose ribavirin: evidence from the Toronto outbreak of severe acute respiratory syndrome. Pharmacotherapy. 2007; 27(4): 494-503. PubMed Abstract | Publisher Full Text
77. Devine EB, Kowdley KV, Veenstra DL, et al.: Management strategies for ribavirin-induced hemolytic anemia in the treatment of hepatitis C: clinical and economic implications. Value Health. 2001; 4(5): 376-84.

PubMed Abstract | Publisher Full Text

78. Ergonul O: Evidence supports ribavirin use in Crimean-Congo hemorrhagic fever. Int J Infect Dis. 2014; 29: 296.

PubMed Abstract | Publisher Full Tex

79. Ergonul O: DEBATE (see Elaldi $\mathbf{N}$ et al, Efficacy of oral ribavirin treatment in Crimean-Congo haemorrhagic fever: a quasi-experimental study from Turkey. Journal of Infection 2009; 58: 238-244): Biases and misinterpretation in the assessment of the efficacy of oral ribavirin in the treatment of Crimean-Congo hemorrhagic fever. J Infect. 2009; 59(4): 284-6; author reply 286-9. PubMed Abstract | Publisher Full Text

80. Ceylan B, Calıca A, Ak O, et al:: Ribavirin is not effective against CrimeanCongo hemorrhagic fever: Observations from the Turkish experience. Int $J$ Infect Dis. 2013; 17(10): e799-801.

PubMed Abstract | Publisher Full Text

81. Ascioglu S, Leblebicioglu H, Elaldi N, et al.: Response to Ergonul: Scientific Evidence Versus Personal Beliefs In Crimean-Congo Haemorrhagic Fever Treatment. J Infect. 2009; 59(4): 286-9. Publisher Full Text

82. Arda B, Aciduman A, Johnston JC: A randomised controlled trial of ribavirin in Crimean Congo haemorrhagic fever: Ethical considerations. $J$ Med Ethics. 2012; 38(2): 117-20.

PubMed Abstract | Publisher Full Text

83. Furuta $\mathrm{Y}$, Takahashi $\mathrm{K}$, Fukuda $\mathrm{Y}$, et al.: In vitro and in vivo activities of antiinfluenza virus compound T-705. Antimicrob Agents Chemother. 2002; 46(4): 977-81.

PubMed Abstract | Publisher Full Text | Free Full Text

84. F Oestereich L, Lüdtke A, Wurr S, et al:: Successful treatment of advanced Ebola virus infection with T-705 (favipiravir) in a small animal model. Antiviral Res. 2014; 105: 17-21.

PubMed Abstract | Publisher Full Text | F1000 Recommendation

85. Rosenke K, Feldmann H, Westover JB, et al.: Use of Favipiravir to Treat Lassa Virus Infection in Macaques. Emerg. Infect. Dis. 2018; 24(9): 1696-9. PubMed Abstract | Publisher Full Text | Free Full Text

86. Safronetz D, Rosenke K, Westover JB, et al:: The broad-spectrum antiviral favipiravir protects guinea pigs from lethal Lassa virus infection post-disease onset. Sci Rep. 2015; 5: 14775.

PubMed Abstract | Publisher Full Text | Free Full Text

87. Raabe VN, Kann G, Ribner BS, et al:: Favipiravir and Ribavirin Treatment of Epidemiologically Linked Cases of Lassa Fever. Clin Infect Dis. 2017; 65(5): 855-9.

PubMed Abstract | Publisher Full Text | Free Full Text

88. F Welch SR, Scholte FEM, Flint M, et al.: Identification of 2'-deoxy-2'fluorocytidine as a potent inhibitor of Crimean-Congo hemorrhagic fever virus replication using a recombinant fluorescent reporter virus. Antiviral Res. 2017; 147: 91-9.

PubMed Abstract | Publisher Full Text | F1000 Recommendation

89. F Zivcec M, Guerrero LIW, Albariño CG, et al:: Identification of broadly neutralizing monoclonal antibodies against Crimean-Congo hemorrhagic fever virus. Antiviral Res. 2017; 146: 112-20.

PubMed Abstract | Publisher Full Text | F1000 Recommendation 


\section{Open Peer Review}

\section{Current Peer Review Status:}

\section{Editorial Note on the Review Process}

Faculty Reviews are review articles written by the prestigious Members of Faculty Opinions. The articles are commissioned and peer reviewed before publication to ensure that the final, published version is comprehensive and accessible. The reviewers who approved the final version are listed with their names and affiliations.

\section{The reviewers who approved this article are:}

\section{Version 1}

\section{Eric Bergeron}

Viral Special Pathogens Branch, Centers for Disease Control and Prevention, Atlanta, Georgia, USA Competing Interests: No competing interests were disclosed.

\section{Ali Mirazimi}

1 Department for Laboratory Medicine, Karolinska Institute and Karolinska Hospital University, Solna, Sweden

2 National Veterinary Institute, Uppsala, Sweden

Competing Interests: No competing interests were disclosed.

\section{Dennis A Bente}

Department of Microbiology \& Immunology, Galveston National Laboratory, University of Texas Medical Branch, Galveston, TX, 77555-0610, USA

Competing Interests: No competing interests were disclosed.

\section{Anna Papa}

Department of Microbiology, Medical School, Aristotle University of Thessaloniki, Thessaloniki, Greece Competing Interests: No competing interests were disclosed. 
The benefits of publishing with F1000Research:

- Your article is published within days, with no editorial bias

- You can publish traditional articles, null/negative results, case reports, data notes and more

- The peer review process is transparent and collaborative

- Your article is indexed in PubMed after passing peer review

- Dedicated customer support at every stage

For pre-submission enquiries, contact research@f1000.com 